\title{
Pleomorphic Adenoma in the Lower Lip: A Case Report and a Review
}

\author{
Ibrahim Nourwali ${ }^{1, \odot ~ N a j l a ~ D a r-O d e h ~}{ }^{2,3, \odot}$
}

Address for correspondence Najla Dar-Odeh, BDS, FDS RCS-Ed, Department of Oral Basic and Clinical Sciences, College of Dentistry, Taibah University, Al Madinah Al Munawara, Saudi Arabia (e-mail: najla_dar_odeh@yahoo.com).

\begin{abstract}
Keywords

- case report

- lower lip

- pleomorphic adenoma

- salivary gland

- squamous metaplasia

Pleomorphic adenoma constitutes $50 \%$ of salivary gland tumors affecting mostly the parotid gland extraorally, and the palate intraorally. While the upper lip is a common site, it is unusual to encounter this tumor in the lower lip. A 26-year-old man complained of a persistent lump affecting the lower lip. The lesion was excised and was shown on histopathological examination to be a pleomorphic adenoma with squamous metaplasia. At the 18-month review appointment, there was complete healing and no recurrence. Pleomorphic adenoma in the lower lip should be considered among the differential diagnosis of lower labial swellings, especially in young patients. There needs to be reconsideration of the epidemiological and histological characteristics.
\end{abstract}

\section{Introduction}

Pleomorphic adenoma is the most common salivary gland tumor comprising $50 \%$ of all salivary gland tumors and $40 \%$ of intraoral salivary gland tumors. ${ }^{1}$ The name is derived from the varied histopathologic structure of the neoplasm; it consists of an encapsulated proliferation of ductal and myoepithelial cells supported by a stroma that varies from dense hyalinized collagen to loosely arranged ground substance with the possibility of presence of cartilage and bone. The age prevalence of pleomorphic adenoma varies from the second decade onwards with a predilection for females. ${ }^{1}$ Parotid is the most common extraoral site, while intraorally, the palate is the most common site followed by the upper lip and the buccal mucosa. ${ }^{1}$ Labial pleomorphic adenoma constitutes 20 to $40 \%$ of all intraoral pleomorphic adenomas ${ }^{2}$ however, most labial salivary gland tumors arise in the upper lip. ${ }^{1}$ The lower lip is considered a rare site of occurrence for this tumor constituting $<3 \%$ of all intraoral pleomorphic adenomas. ${ }^{3}$ The clinical presentation of intraoral pleomorphic adenoma is that of a unilateral, painless, slow-growing submucosal mass covered by intact epithelium, with few cases of ulceration, pain, and bleeding being also reported. Some lesions may consist of a cystic component, develop a bluish appearance, and consequently become clinically indistinguishable from a deeply seated mucocele or mucoepidermoid carcinoma. ${ }^{2} \mathrm{Few}$ cases of lower lip pleomorphic adenoma were reported. ${ }^{4-9}$ Scientific literature written in English reveals a small number of case reports on pleomorphic adenoma of the lower lip; most of them were reported in Asian countries, and Brazil. - Table 1 describes all cases of labial pleomorphic adenoma that were reported between 2000 and 2019.

Here, we describe a case of pleomorphic adenoma in the lower lip of a 26-year-old man including diagnosis (histological and radiographic findings) and surgical management.

\section{Case Report}

A 26-year-old man of Egyptian descent attended for the complaint of a firm lump affecting the lower lip that has been slowly growing since the past 2 years and causing discomfort. There was no pain or infection associated with the lump. The patient was nonsmoker, nondrinker, and he worked as a clerk. The patient also reported no medical history of any significant diseases. Upon examination, there was no submandibular or cervical lymphadenopathy. Intraorally, the patient had generalized periodontitis, carious teeth, and severe gum recession around lower central incisors. The lesion was felt as a firm, nontender submucosal mass of $2.5 \times 2.0 \mathrm{~cm}$ diameter affecting the lower lip. There was a mild elevation of 
Table 1 Cases of pleomorphic adenoma that were reported between 2000 and 2019 affecting the upper lip (UL), and lower lip $(\mathrm{LL})$ in both males (M) and females (F)

\begin{tabular}{|c|c|c|c|c|c|c|c|}
\hline Authors (y) & Site & $\begin{array}{l}\text { Country/ } \\
\text { ethnicity }\end{array}$ & Gender & $\begin{array}{l}\text { Age } \\
\text { (y) }\end{array}$ & Prognosis & Follow-upa & Special remarks \\
\hline Alves et al $(2018)^{10}$ & UL & Brazil & $M$ & 18 & Good & $24 \mathrm{mo}$ & \\
\hline $\begin{array}{l}\text { Mair and Aguirre } \\
(2016)^{11}\end{array}$ & UL & USA & M & 62 & Good & $24 \mathrm{mo}$ & \\
\hline Khan et al $(2016)^{12}$ & UL & Pakistan & $M$ & 60 & NA & NA & \\
\hline Fatahzadeh $(2017)^{13}$ & UL & USA & $\mathrm{M}$ & 58 & NA & NA & \\
\hline Ahmedi et al (2017) ${ }^{14}$ & UL & Kosova & $\mathrm{F}$ & 10 & Good & $12 \mathrm{mo}$ & \\
\hline Fomete et al $(2015)^{15}$ & UL & Nigeria & $\mathrm{F}$ & 37 & NA & NA & \\
\hline Mariano et al $(2013)^{16}$ & UL & Brazil & M & 69 & Good & $30 \mathrm{mo}$ & Carcinoma ex PA \\
\hline Singh et al $(2015)^{17}$ & UL & India & M & 55 & Good & $6 \mathrm{mo}$ & \\
\hline Mitate et al $(2013)^{18}$ & UL & Japan & M & 55 & Good & $6 y$ & Carcinoma ex PA \\
\hline Küçük and Tan (2011) ${ }^{19}$ & UL & Turkey & $M$ & 35 & NA & NA & \\
\hline Taiwo et al $(2018)^{20}$ & UL & Nigeria & M & 33 & Good & $6 \mathrm{mo}$ & \\
\hline Stander et al $(2013)^{21}$ & UL & African & $\mathrm{F}$ & 47 & Good & NA & \\
\hline Tzermpos et al $(2014)^{22}$ & UL & Caucasian & $\mathrm{F}$ & 39 & Good & $3 y$ & \\
\hline Lotufo et al $(2008)^{23}$ & UL & Brazil & $\mathrm{M}$ & 12 & Good & $1 \mathrm{y}$ & \\
\hline Asuquo et al (2009) ${ }^{24}$ & UL & African & $\mathrm{F}$ & 50 & Good & $3 \mathrm{mo}$ & \\
\hline Asuquo et al $(2009)^{24}$ & UL & African & $\mathrm{F}$ & 40 & Good & $26 \mathrm{mo}$ & \\
\hline Jorge et al $(2002)^{3}$ & UL & Brazil & $\mathrm{F}$ & 15 & Good & $5 y$ & \\
\hline Jorge et al $(2002)^{3}$ & UL & Brazil & $\mathrm{F}$ & 18 & Good & $39 y$ & \\
\hline Dyalram et al $(2012)^{25}$ & UL & $\begin{array}{l}\text { African } \\
\text { American }\end{array}$ & M & 72 & Good & $8 \mathrm{mo}$ & Carcinoma ex PA \\
\hline $\begin{array}{l}\text { McNamara et al } \\
(2009)^{26}\end{array}$ & UL & Australia & $\mathrm{F}$ & 55 & Good & $18 \mathrm{mo}$ & Carcinoma ex PA \\
\hline Kataria et al $(2011)^{27}$ & UL & India & $\mathrm{F}$ & 65 & Good & $1 \mathrm{y}$ & \\
\hline Ali et al $(2011)^{28}$ & UL & India & $\mathrm{M}$ & 33 & Good & $1 \mathrm{y}$ & \\
\hline $\begin{array}{l}\text { Debnath and Adhyapok } \\
(2010)^{29}\end{array}$ & UL & India & $\mathrm{F}$ & 55 & Good & $1 \mathrm{y}$ & \\
\hline Sood et al $(2014)^{5}$ & $\mathrm{LL}$ & Asian & $\mathrm{M}$ & 46 & NA & NA & \\
\hline To et al $(2002)^{6}$ & $\mathrm{LL}$ & Hong Kong & $\mathrm{M}$ & 25 & Good & $24 \mathrm{mo}$ & \\
\hline Sengul et al $(2011)^{30}$ & $\mathrm{LL}$ & Turkey & $M$ & 49 & Good & $40 \mathrm{mo}$ & \\
\hline
\end{tabular}

Abbreviation: PA, pleomorphic adenoma.

${ }^{a}$ Follow-up duration is in months (mo), years (y), or not available (NA).

the lower right labial mucosa slightly crossing the midline (-Fig. 1). Considering that the lesion was painless, slowly growing, and firm in consistency, an initial diagnosis of mesenchymal tumor (fibroma) was established. Further, a differential diagnosis was considered to include benign tumors arising from labial tissues in general such as pleomorphic adenoma, canalicular adenoma, fibroma/neurofibroma, and granular cell tumor.

Panoramic radiograph showed a calcified mass in the lip and alveolar bone resorption of lower anterior teeth (-Fig. 2A). Ultrasound examination revealed a well-defined submucosal hypoechoic soft tissue mass of approximately $2.3 \times 2.2 \times 1.8 \mathrm{~cm}$ (-Fig. 2 B)

The lesion showed large areas of calcifications with no evidence of increased abnormal vascularity on color Doppler interrogation. Based on the presence of the calcified mass found in the lesion, sialolithiasis was considered as another differential diagnosis in addition to pleomorphic adenoma containing a cartilaginous/bony component.

It was decided to do an excisional biopsy. The patient was given bilateral mental nerve block using $6 \mathrm{~mL}$ of $2 \%$ mepivacaine with epinephrine. The mass was $2.0 \times 2.0 \mathrm{~cm}$ and it was 
completely encapsulated. The lesion was excised ( $\mathbf{- F i g . ~ 3 )}$ and sent for histopathology.

Histopathological report revealed that the mass was composed of myxoid spindle-shaped cells intermingled with highly cellular areas formed mainly of myoepithelial cells with glandular and papillary formations. Other areas showed dense stromal fibrosis with solid sheets of myoepithelial cells, and squamous metaplasia ( - Fig. 4 ).

Scattered foci of cartilage and bone formation were also seen in between. One month postoperatively the patient showed good healing of the wound. He was reviewed 18 months postoperatively; there was no recurrence, and

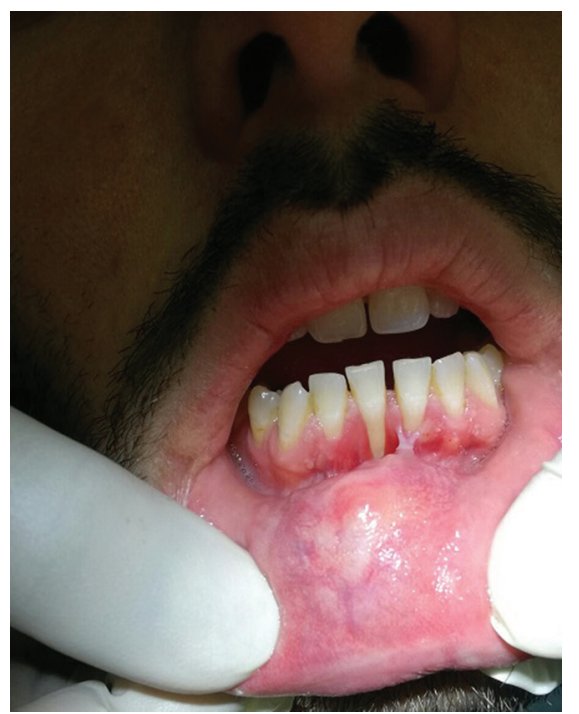

Fig. 1 Swelling of the right lower labial mucosa extending slightly to the left side associated with severe gum recession around lower central incisors.

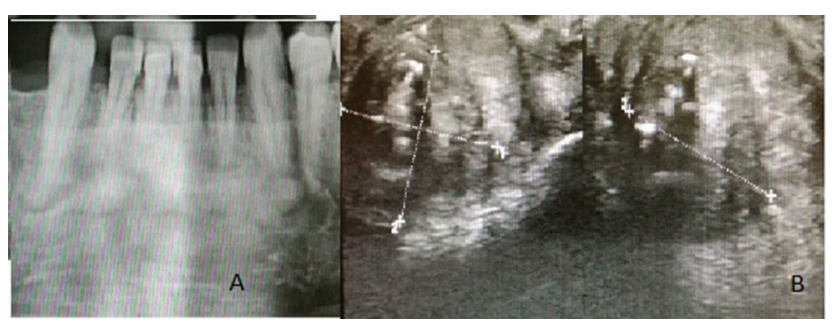

Fig. 2 Panoramic radiograph (A) and ultrasound examination (B) showing multiple calcifications in the lesion.

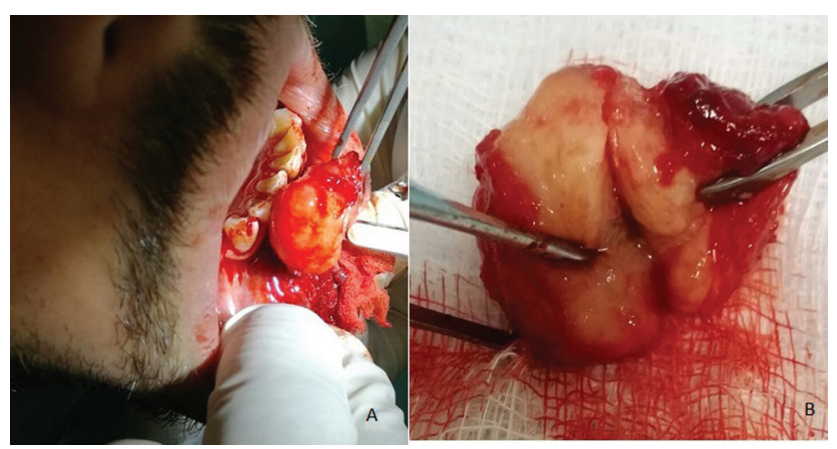

Fig. 3 Pleomorphic adenoma during (A) and after (B) excision. there was improvement in the gingival recession associated with the lower incisors (-Fig. 5).

\section{Discussion}

Salivary gland tumors are considered rare with a prevalence of 2.5 to 3 per 100,000 per year in the Western world, with approximately $80 \%$ of these lesions being benign. ${ }^{1}$ Among these benign lesions, pleomorphic adenoma is considered a well-described tumor. There is a possibility, however, for confusion in histological interpretation particularly in small incisional biopsies due to the heterogeneity of the morphological patterns. ${ }^{1}$ This morphogenic complexity is attributed to differentiation of the tumor cells into fibrous, hyalinized, myxoid, chondroid, and even osseous tissue. In the past two decades, several advanced diagnostic techniques have been developed to examine surgical specimens of salivary

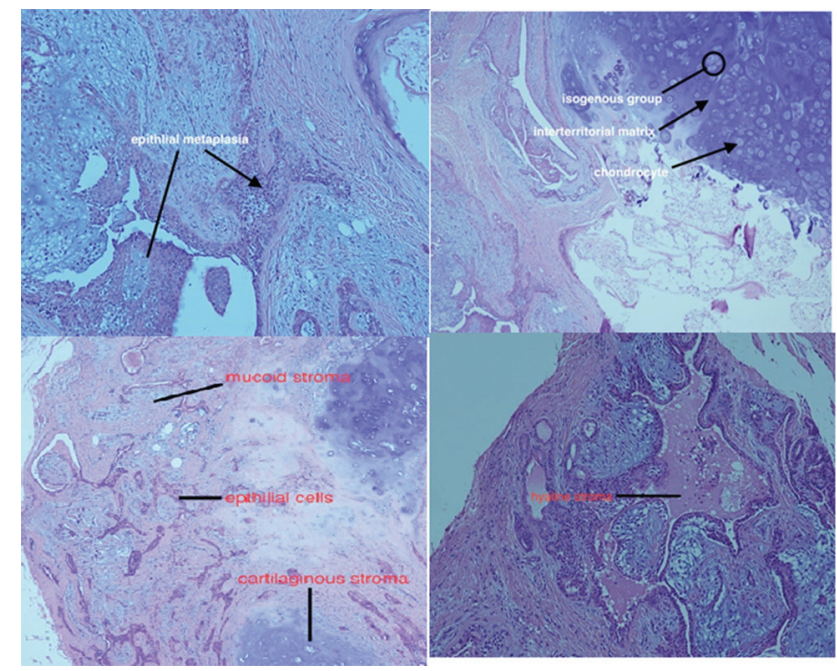

Fig. 4 Histological findings.

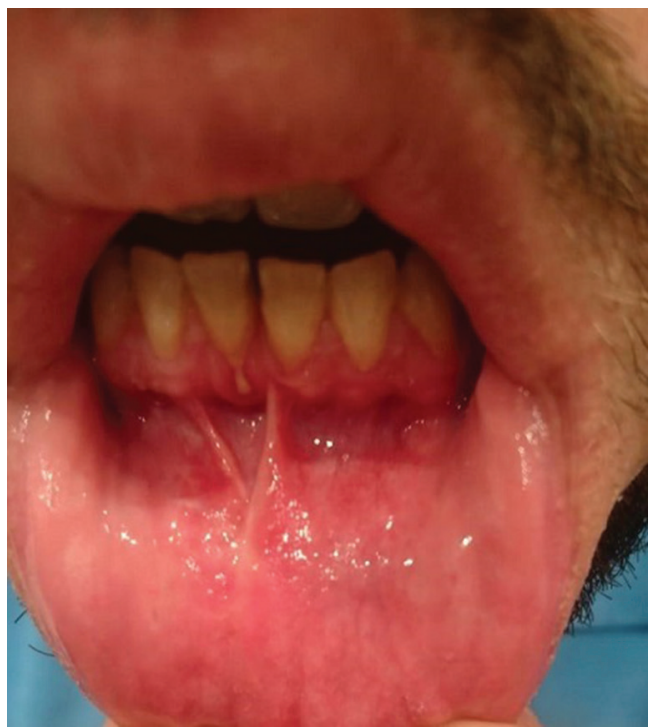

Fig. 5 Retracted lower lip to show complete healing and no recurrence after 18 months of surgery. There was an associated scar and improvement of the gingival recession. 
gland neoplasms, and they proved to be effective especially in small biopsies or in challenging cases for which histology and immunohistochemistry alone are not sufficient to reach a definite diagnosis. ${ }^{31}$ Such techniques include fluorescence in situ hybridization, polymerase chain reaction, and next-generation sequencing. Several primary antibodies have been developed and utilized to target specific aberrant gene products in pleomorphic adenoma, including PLAG1 and HMGA2. ${ }^{32}$

Another important aspect of pleomorphic adenoma is its potential to show cancerous, or metaplastic changes, the latter affecting approximately $25 \%$ of pleomorphic adenomas. ${ }^{33}$ Carcinoma arising in pleomorphic adenoma is due to transformation of benign lesions into malignancy, and it accounts for approximately $3 \%$ of salivary tumors. ${ }^{7}$ Progression to carcinoma is a multistage process that is preprogrammed temporarily in the genome. ${ }^{34}$ These carcinomas tend to be larger and longer standing than benign lesions, ${ }^{1}$ and they tend to affect an older age group with an average age of presentation of 60 years. ${ }^{2}$ Cases reported in the past two decades show that carcinoma ex pleomorphic adenoma affects both males and females above 50 years of age in a ratio of 3:1 (-Table $\mathbf{1}$ ). A challenging aspect in the management of pleomorphic adenoma arises from the nature of its capsule because it is known to have microscopic pseudopod-like extensions into the surrounding tissues consequently leading to recurrence. ${ }^{35}$ Pleomorphic adenoma is probably the only benign salivary gland neoplasm that may exhibit such pseudopods or focal infiltration into the adjacent normal salivary gland tissue. ${ }^{31}$ Moreover, recurrent pleomorphic adenoma often presents with numerous miliary nodules in the surgical bed. ${ }^{31}$ However, this could be a problem peculiar to parotid and not labial tumors due to the characteristic anatomical features of the parotid gland.

The differential diagnosis of a persistent slowly growing asymptomatic mass in the lip should include benign lesions ${ }^{36}$ originating in tissues that form the lip including other minor salivary gland tumors, and mesenchymal lesions such as neurofibroma and schwannoma which usually occurs in adults of a younger age group. ${ }^{37}$ The calcified mass seen on radiographic examination of the lesion in this case was explained as a sialolithe or pleomorphic adenoma. However, sialolithiasis is a rare occurrence in minor salivary glands where the upper lip and buccal mucosa are the most commonly affected areas. ${ }^{38}$

To et al stated that labial pleomorphic adenoma tends to occur at an earlier age than it does at other sites. ${ }^{6}$ Indeed, in this case report the patient was in the third decade of life similar to other case reports. ${ }^{6}$ Pleomorphic adenomas tend to be soft in consistency; however, in this case, it was firm due to its component of cartilage and bone which could be found in such a tumor.

Prognosis of pleomorphic adenoma is usually good as also reported from literature., ${ }^{4,6}$ Although some believe that salivary tumors of the lower lip tend to be malignant, while those of the upper lip tend to be benign. However, case reports on lower lip pleomorphic adenoma generally report a good prognosis and no recurrence on follow-up for 2 to 4 years. $4,6,7$

Squamous metaplasia was observed in this case. This is an incidental finding in some benign and malignant tumors. ${ }^{39}$ Its origin is not clear, and it has been associated with a traumatic event leading to infarction/ischemia and repair following infarction..$^{40}$ Sharma et al reported that fine needle aspiration of the tumor could be a cause of trauma and development of squamous metaplasia later. ${ }^{39}$ In our case, there was no history of trauma, as the lesion was excised surgically with no prior traumatic investigations. The transformation of squamous metaplasia into squamous cell carcinoma cannot be excluded and should be considered in determining the prognosis. ${ }^{41}$ Close monitoring of the patient and a review conducted at 18 months postoperatively confirmed no recurrence and no development of malignant change. Further, it seems that the persistent pleomorphic adenoma in the patient's lower lip was a major factor contributing to the severe gingival recession around lower central incisors. A careful follow-up of this patient is needed for two main reasons: to monitor the patient for the potential of recurrence for this tumor, and to provide the proper periodontal management.

In conclusion, this report documents peculiar findings in this case of pleomorphic adenoma; occurring in the lower lip, affecting a young male, and characterized by, among common histological features of pleomorphic adenoma, squamous metaplasia. The latter finding confirms that the best therapeutic approach should be to excise the lesion including its capsule and a safety margin. Future research should aim to answer gaps in knowledge concerning this type of tumor such as predisposing factors, histological features, and cancerous transformation particularly that several cases reported neglected to mention prognosis or follow-up data (-Table 1).

\section{Ethical Aspects}

All procedures performed in this study were in accordance with the ethical standards of the institutional research committee and with the 1964 Helsinki Declaration and its later amendments or comparable ethical standards.

\section{Informed Consent}

Informed consent was obtained from the patient whose case was reported in this study.

\section{Funding}

None.

\section{Conflict of Interest}

None declared.

\section{Acknowledgments}

The authors are grateful to Dr. Hamzah Babcair for his assistance in histopathological interpretation, and Professor Ali Shamaa, College of Dentistry, Taibah University, for his assistance in preparing the photomicrographs. They would also like to thank the staff in Saudi-German Hospital, Al Madinah, for making this study possible. 


\section{References}

1 Speight PM, Barrett AW. Salivary gland tumours. Oral Dis 2002;8(5):229-240

2 Eveson JW, Cawson RA. Tumours of the minor (oropharyngeal) salivary glands: a demographic study of 336 cases. J Oral Pathol 1985;14(6):500-509

3 Jorge J, Pires FR, Alves FA, et al. Juvenile intraoral pleomorphic adenoma: report of five cases and review of the literature. Int J Oral Maxillofac Surg 2002;31(3):273-275

4 Sengul I, Sengul D. Pleomorphic adenoma of the lower lip: a review. N Am J Med Sci 2011;3(12):536-539

5 Sood A, Chung S, Datiashvili RO. An incidental finding of pleomorphic adenoma of the minor salivary glands in the skin area of the lower lip. Eplasty 2014;14:e39

6 To EWH, Tsang WM, Tse GMK. Pleomorphic adenoma of the lower lip: report of a case. J Oral Maxillofac Surg 2002;60(6):684-686

7 Yamamoto H, Fukumoto M, Matsumoto T, et al. Pleomorphic adenoma of the lower lip: a case and review of the Japanese literature. J Nihon Univ Sch Dent 1985;27(3):189-194

8 Taniguchi K, Naito H, Mori K, Kawano M, Nakashima T. A case of pleomorphic adenoma of the lower lip Japanese J Oral Diagnosis/Oral Med 2016;26(2):86-91

9 Adachi M, Yoshino A, Yanai C, Shirakawa M, Nonaka H. A case of pleomorphic adenoma of the lower lip Japanese J Oral Maxillofac Surg; 2011. doi: 10.5794/jjoms.44.61

10 Alves VLA, Pérez-de-Oliveira ME, de Castro JFL, Vieira CL, Leão JC, Perez DEC. Intraoral pleomorphic adenoma in young patients. J Craniofac Surg 2018;29(2):e209-e211

11 Mair Y, Aguirre A. Upper lip swelling. J Am Dent Assoc 2016;147(11):898-901

12 Khan MN, Raza SS, Hussain Zaidi SA, et al. Pleomorphic adenoma of minor salivary glands. J Ayub Med Coll Abbottabad 2016;28(3):620-622

13 Fatahzadeh M. Pleomorphic adenoma of the upper lip: a rare case. N Y State Dent J 2017;83(2):47-51

14 Ahmedi JR, Ahmedi E, Perjuci F, et al. Pleomorphic adenoma of minor salivary glands in child. Med Arh 2017;71(5):360-363

15 Fomete B, Adeosun 00, Awelimobor DI, Olayemie L. Recurrent pleomorphic adenoma of the upper lip: case report and review of the literature. Niger J Med 2015;24(3):277-280

16 Mariano FV, Rincon D, Gondak RO, et al. Carcinoma ex-pleomorphic adenoma of upper lip showing copy number loss of tumor suppressor genes. Oral Surg Oral Med Oral Pathol Oral Radiol 2013;116(1):69-74

17 Singh A, Kumar N, Sharma P, Singh S. Pleomorphic adenoma involving minor salivary glands of upper lip: a rare phenomenon. J Cancer Res Ther 2015;11(4):1025

18 Mitate E, Kawano S, Kiyoshima T, et al. Carcinoma ex pleomorphic adenoma of the upper lip: a case of an unusual malignant component of squamous cell carcinoma. World J Surg Oncol 2013;11:234

19 Küçük Ü, Tan S. Pleomorphic adenoma of the upper lip. Turk Patoloji Dergisi/Turkish. J Pathol 2011; 4(3):217-219

20 Taiwo AO, Akinshipo A, Braimah ROIA, Ibikunle AA. Pleomorphic adenoma of the upper lip: a case report. Saudi J Med Med Sci 2018;6(1):32-35

21 Stander S, Mulder-Van Staden S, Cheung TY, Dreyer WP, Mohamed N, Afrogheh A. Oral medicine case book 52: pleomorphic adenoma of the upper lip. SADJ 2013;68(7):328-330

22 Tzermpos F, Chatzichalepli C, Cocos A, Kleftogiannis M, Zarakas M, Chrysomali E. Atypical presentation of an upper lip pleomorphic adenoma: case report. Acta Stomatol Croat 2014;48(1):48-53

23 Lotufo MA, Júnior CAL, Mattos JP, França CM. Pleomorphic adenoma of the upper lip in a child. J Oral Sci 2008;50(2):225-228

24 Asuquo ME, Otei OO, Ekpo R, et al. Salivary gland tumour of the lip: report of two cases and literature review. Cent Afr J Med 2009;55(5-8):43-46

25 Dyalram D, Huebner T, Papadimitriou JC, Lubek J. Carcinoma ex pleomorphic adenoma of the upper lip. Int J Oral Maxillofac Surg 2012;41(3):364-367

26 McNamara ZJ, Batstone M, Farah CS, Carcinoma ex pleomorphic adenoma in a minor salivary gland of the upper lip Oral Surg Oral Med Oral Pathol Oral Radiol Endod; 2009 108(5):e51-e53

27 Kataria SP, Tanwar P, Sethi D, Garg M. Pleomorphic adenoma of the upper lip. J Cutan Aesthet Surg 2011;4(3):217-219

28 Ali I, Gupta AK, Singh S. Pleomorphic adenoma of the upper lip. Natl J Maxillofac Surg 2011;2(2):219-221

29 Debnath SC, Adhyapok AK. Pleomorphic adenoma (benign mixed tumour) of the minor salivary glands of the upper lip. J Maxillofac Oral Surg 2010;9(2):205-208

30 Sengul I, Sengul D, Aribas D. Pleomorphic adenoma of the lower lip: a rare site of location. N Am J Med Sci 2011;3(6):299-301

31 Katabi N, Xu B. Salivary gland neoplasms: diagnostic approach with focus on patterns of recognition and useful ancillary tools. Diagn Histopathol 2018;

32 Katabi N, Xu B, Jungbluth AA, et al. PLAG1 immunohistochemistry is a sensitive marker for pleomorphic adenoma: a comparative study with PLAG1 genetic abnormalities. Histopathology 2018;72(2):285-293

33 Lam KY, Ng IO, Chan GS. Palatal pleomorphic adenoma with florid squamous metaplasia: a potential diagnostic pitfall. J Oral Pathol Med 1998;27(8):407-410

34 Sridevi U, Jain A, Nagalaxmi V, Kumar UV, Goyal S. Expression of E-cadherin in normal oral mucosa, in oral precancerous lesions and in oral carcinomas. Eur J Dent 2015;9(3):364-372

35 Hamada T, Matsukita S, Goto M, et al. Mucin expression in pleomorphic adenoma of salivary gland: a potential role for MUC1 as a marker to predict recurrence. J Clin Pathol 2004;57(8):813-821

36 Tozoglu S, Hatipoglu M, Aytekin Z, Gurer EI. Extensive ameloblastic fibroma of the mandibula in a female adult patient: a case report with a follow-up of 3 years. Eur J Dent 2016;10(1):139-143

37 Gudi SS, Sikkerimath BC, Puranik RS, Kasbe SS. Swelling on lower lip...not always a mucocele!!! Ann Maxillofac Surg 2013;3(1):98-99

38 Alcure ML, Della Coletta R, Graner E, Di Hipolito O, Jr. Lopes MA. Sialolithiasis of minor salivary glands: a clinical and histopathological study. Gen Dent 2005;53(4):278-281

39 Sharma S, Mehendiratta M, Chaudhary N, Gupta V, Kohli M, Arora A. Squamous metaplasia in pleomorphic adenoma: a diagnostic and prognostic enigma. J Pathol Transl Med 2018;52(6):411-415

40 Kaveri H, Gopalkrishnana K, Venkatesh A. Cystic and florid squamous metaplasia in pleomorphic adenoma of palate - a diagnostic dilemma. Asian J Med Sci 2014;5(4):108-110

41 Takegawa K, Mitsumori K, Onodera H, et al. Induction of squamous cell carcinomas in the salivary glands of rats by potassium iodide. Jpn J Cancer Res 1998;89(2):105-109 